\title{
Re-Evaluation of HER2 Status in Metastatic Breast Cancer and Tumor-Marker Guided Therapy with Vinorelbine and Trastuzumab
}

\author{
Hans-Joachim Stemmler ${ }^{\mathrm{a}}$ Petra Stieber ${ }^{\mathrm{b}} \quad$ Dorit Lässig $^{\mathrm{b}}$ Volker Heinemann ${ }^{\mathrm{a}}$ \\ ${ }^{a}$ Medizinische Klinik III, Hämatologie - Onkologie, \\ ${ }^{\mathrm{b}}$ Institut für Klinische Chemie, LMU München, Klinikum Großhadern, Germany
}

\section{Key Words}

Vinorelbine - Trastuzumab - Breast cancer, metastatic . Chemotherapy $\cdot$ HER2 - HER2 shed antigen

\section{Summary}

Background: HER2 is overexpressed in $20-30 \%$ of breast cancers. Compared to chemotherapy alone, chemotherapy with trastuzumab improves clinical outcome in patients with HER2-positive metastatic breast cancer (MBC). In general, HER2 status in a primary lesion predicts the status of metastases, so that biopsy of metastatic lesions appears unnecessary. Case Report: A 39-year old woman was diagnosed with primary breast cancer in November 2000. Using the method and scoring system of the DAKO Hercep Test, the tumor has shown low HER2 expression (DAKO score $1+)$. After failure of several chemotherapy regimens for metastatic disease (liver, skeletal), the patient underwent CT-guided needle biopsy of the liver which showed HER2 positive adenocarcinoma (DAKO score $3+$ ). In consequence, the patient was treated with vinorelbine $\left(30 \mathrm{mg} / \mathrm{m}^{2}\right.$ $\mathrm{d} 1,8,15 \mathrm{q} 4 \mathrm{w}$ ) and trastuzumab (4 $\mathrm{mg} / \mathrm{kg}$ loading dose, $2 \mathrm{mg} / \mathrm{kg}$ weekly). During a treatment period of 4 months imaging results as well as tumor marker kinetics indicated an excellent response with sustained decrease of tumor markers. A retrospective analysis of the HER2 shed antigen in metastatic stage revealed excessively increased serum levels and supports HER2 overexpression observed in liver metastasis. The kinetics of the HER2 shed antigen during therapy for metastatic disease were found to be in phase with the kinetics of CEA and CA15-3. Conclusion: This case report demonstrates that re-evaluation of the HER2 status may be helpful in single patients not sufficiently responding to treatment of metastatic disease. Determination of HER2 overexpression may be facilitated by a determination of the HER2 shed antigen level in peripheral blood.
Schlüsselwörter

Vinorelbin - Trastuzumab - Mammakarzinom, metastasiertes . Chemotherapie · HER2 - HER2-shed-Antigen

\section{Zusammenfassung}

Hintergrund: HER2 wird bei $20-30 \%$ der Patientinnen mit Brustkrebs überexprimiert. Im Vergleich zur alleinigen Chemotherapie wird die Ansprechrate durch die Kombination mit Trastuzumab deutlich verbessert. Üblicherweise darf man davon ausgehen, dass der HER2 Status, der am Primärtumor erhoben wurde, dem der Metastasen entspricht, so dass von einer erneuten Biospie der Metastasen in der Regel abgesehen werden kann. Fallbericht: Wir berichten über eine 39-jährige Patientin mit der Diagnose eines Mammakarzinoms das bei Primärdiagnose im DAKO Hercep Test keine HER2 Überexpression aufwies (DAKO score 1+). Aufgrund einer Leber- und Knochenmetastastasierung wurde die Patientin mit mehreren Chemotherapieschemata behandelt, die jedoch zu keiner anhaltenden Remission führten. Eine erneute histologische Sicherung durch eine CT-gesteuerte Leberbiopsie ergab den Befund eines deutlich HER2 überexprimierenden Adenokarzinoms (DAKO score 3+). Daraufhin wurde die Patientin mit einer Kombinationstherapie aus Vinorelbin $\left(30 \mathrm{mg} / \mathrm{m}^{2} \mathrm{~d} 1,8,15\right.$ $\mathrm{q} 4 \mathrm{w}$ ) und Trastuzumab weiterbehandelt $(4 \mathrm{mg} / \mathrm{kg}$ loading dose, $2 \mathrm{mg} / \mathrm{kg}$ wöchentlich). Nach nunmehr 4-monatiger Therapie zeigt sich sowohl in den bildgebenden Verfahren als auch anhand der Tumormarkerkinetik eine eindeutige Tumorremission. Eine retrospektive Analyse des HER2shed-Antigens zeigte zum Zeitpunkt der Diagnose der Metastasierung exzessiv erhöhte Spiegel und untermauert damit den Befund der HER2 überexprimierenden Lebermetastasierung. Die Kinetik dieses Markers verhielt sich dabei analog zur Tumormarkerkinetik von CEA und CA15-3. Schlussfolgerung: Der vorliegende Fall zeigt, dass eine Re-Evaluierung des HER2 Status bei Patientinnen, die nur ungenügend auf eine palliative Chemotherapie ansprechen, hilfreich sein kann. Die Re-Evaluierung der HER2 Überexpression kann dabei durch die Bestimmung des HER2-shed-Antigens im Serum wesentlich vereinfacht werden.

\begin{tabular}{ll}
\hline KARGER & @ 2005 S. Karger GmbH, Freiburg \\
Fax +497614520714 & Accessible online at: \\
$\begin{array}{l}\text { E-mail Information@Karger.de } \\
\text { www.karger.com }\end{array}$ & www.karger.com/onk
\end{tabular}




\section{Introduction}

Therapy for metastatic breast cancer is guided by biologic features of the tumor. Patients with tumors overexpressing the human epidermal growth factor receptor 2 (HER2) are candidates for treatment with trastuzumab. Compared to chemotherapy alone, chemotherapy combined with trastuzumab improves clinical outcome, including response rate, time to progression and overall survival in patients with HER2-positive metastatic breast cancer [1-4].

HER2 overexpression in breast cancer is generally determined by immunehistochemistry (IHC), and in a subgroup of patients (DAKO score 2+) by fluorescence in situ hybridization (FISH). Fragments of HER2 receptor corresponding to the extracellular domain (ECD) of HER2 are often shed into serum (HER2 shed antigen) and thus, serum may provide suitable samples for HER2 analysis. Burstein and collegues found that a lack of decline in HER2 shed antigen levels was a predictor for tumor progression after one cycle of chemotherapy [3].

Vinorelbine has synergistic interactions with trastuzumab in laboratory analyses of HER2 overexpressing breast tumor cell lines. In clinical phase II trials, the combination of trastuzumab and vinorelbine was found to be highly effective and safe in first- and second-line treatment of metastatic breast cancer $[3,4]$.

In general, HER2 status in a primary lesion predicts the status of metastatic lesions (87.6-98\%). Therefore, biopsy of metastatic lesions is unnecessary if archival samples from the primary tumor can be accessed [5-8]. The present case demonstrates the clinical course of a patient who presented with an IHC score of HER2 1+ when the primary tumor was evaluated at first diagnosis of breast cancer. In the later course of metastatic disease, biopsy of a hepatic metastasis revealed an IHC score of $3+$ leading to a combination therapy with vinorelbine and trastuzumab.

\section{Case Report}

A 39-year-old woman was diagnosed with left-sided breast cancer in November 2000 ( $\mathrm{pT}_{2}, \mathrm{pN}_{2}$ (bii), $\mathrm{M}_{0}, \mathrm{G}_{3}, \mathrm{~L}_{1}, \mathrm{~V}_{0}, \mathrm{R}_{0}$ ). By IHC examination the tumor was hormone receptor positive (estrogen receptor 8/12, progesterone receptor 12/12 according to the score of Remmele and Stegner [9]) but HER2 was negative (DAKO score $1+$ ).

The patient underwent breast-conserving surgery with level II axilla dissection and was started on adjuvant treatment consisting of 4 cycles epirubicin/cyclophosphamide, radiation therapy and subsequently 3 cycles of docetaxel. After completion of chemotherapy, the patient received adjuvant hormonal therapy with tamoxifen.

In November 2002, liver and skeletal metastases were diagnosed by CT imaging. A combination chemotherapy with capecitabine and docetaxel was begun which was both tolerated well and effective until July 2003, when increasing tumor markers indicated tumor progression. Treatment was continued with 2 cycles of liposomal doxorubicin and in continuation with 4 cycles of gemcitabine and cisplatin. Neither of these treatments proved to be effective, judged by CT scan and tumor marker kinetics.

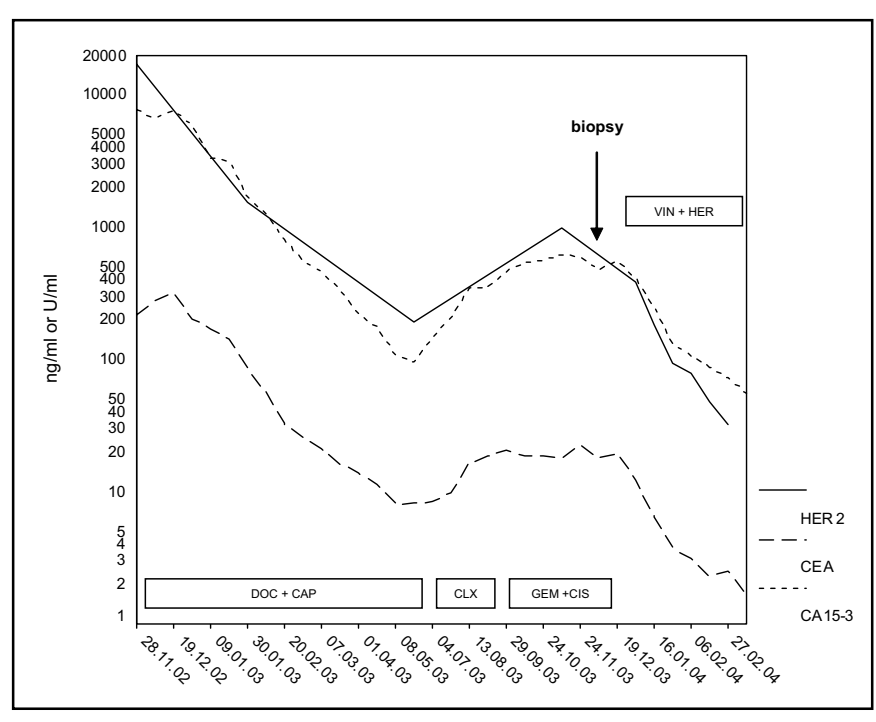

Fig. 1. CEA (Abbott; ng/ml), CA15-3 (Elecsys II; U/ml) and HER2 shed antigen (Centaur; $\mathrm{ng} / \mathrm{ml}$ ) kinetics during chemotherapy.

$\mathrm{DOC}+\mathrm{CAP}=$ Docetaxel and capecitabine; $\mathrm{CLX}=$ liposomal doxorubicin; $\mathrm{GEM}+\mathrm{CIS}=$ gemcitabine and cisplatin; $\mathrm{VIN}+\mathrm{HER}=$ vinorelbine and trastuzumab.

In December 2003, we therefore decided to re-evaluate liver metastasis by CT-guided needle biopsy. The histological and IHC examination detected estrogen-receptor positive adenocarcinoma (ER 12/12, progesterone receptor $0 / 12$ according to the score of Remmele and Stegner), and - surprisingly - an overexpression of HER2 (DAKO score 3+). An IHC re-evaluation of the primary tumor was initiated which confirmed the initial result regarding HER2 and hormone receptor status of the primary (DAKO score $1+$ ). Since previous chemotherapies included a taxane-based regimen, treatment was continued with a combination of vinorelbine $\left(30 \mathrm{mg} / \mathrm{m}^{2} \mathrm{~d} 1,8,15 \mathrm{q} 4 \mathrm{w}\right)$ and trastuzumab (4 mg/ $\mathrm{kg}$ loading dose followed by $2 \mathrm{mg} / \mathrm{kg}$ weekly). Until now (April 2004), this treatment is tolerated well and appears to be highly effective as confirmed by imaging procedures and a steady decrease of tumor markers (fig. 1). A retrospective analysis of HER 2 shed antigen in frozen plasma samples detected an excessively increased level of HER2 shed antigen which was present already at first diagnosis of metastasis. HER2 shed antigen kinetics clearly paralleled the kinetics of the tumor markers CEA and CA15-3.

\section{Discussion}

Breast cancer patients with HER2 overexpressing tumors are candidates for trastuzumab treatment, which improves clinical outcome [1-4]. The addition of trastuzumab to chemotherapy is associated with a longer time to disease progression (median TTP 7.4 vs 4.6 months; $\mathrm{p}<0.001$ ), a higher rate of objective response (50 vs. $32 \% ; p<0.001$ ) and a longer survival (median survival 25.1 vs. 20.3 months; $p=0.046$ ) [2]. As there is a strong correlation of the HER2 status in primary tumors and metastasis, ranging from 87.6 to $98 \%$, it was generally concluded that re-evaluation of the HER2 status by biopsy in metastatic disease is not indicated if archival tissues can be accessed (table 1) $[5-8,10]$. 
Table 1. Concordance of HER2 overexpression in primary tumors and metastatic disease

\begin{tabular}{llll}
\hline Reference & $\mathrm{n}$ & Tumor sites & Concordance, \% \\
\hline Simon et al., 2001 [5] & 196 & primary - metastases & 94 \\
Gancberg et al., 2002 [6] & 105 & primary - metastases & 87.6 \\
Durbecq et al., 2003 [7] & 112 & primary - metastases & 89 \\
Cardoso et al., 2001 [8] & 370 & primary - axillary lymph node & 98 \\
\hline
\end{tabular}

However, a recent study reported by Lüftner et al. [11] has found only a moderate correlation between the HER2 expression of primary tumors and their distant metastases. In 80 pairs of primary breast carcinomas and their metachronous distant metastases, they have found changes from HER2negative primaries to HER2-positive metastases in $17.9 \%$ of pairs as compared to reversed changes from HER2-positive primaries to HER2-negative metastases (6.4\% of pairs). They concluded that clonal changes between primary breast carcinomas and their distant metastases are more frequent than generally assumed.

In the present case, re-evaluation of the HER2 status of the liver metastases was initiated due to rapidly progressing visceral metastasis not responding to aggressive chemotherapy. Since liver metastases overexpressed HER2 at a DAKO score of $3+$, treatment was continued with vinorelbine and trastuzumab from which the patient benefited to a major extent.
A retrospective evaluation of frozen plasma samples for HER2 shed antigen detected excessively increased serum levels at the diagnosis of metastasis. The favorable clinical response to this treatment is well reflected by the kinetics of CEA, CA15-3 and HER2 shed antigen (fig. 1).

Previous reports indicating high response rates of 68 and $75 \%$ achieved by vinorelbine and trastuzumab in HER2-overexpressing breast cancer patients $[3,12,13]$. The combination of vinorelbine and trastuzumab is associated with a very favorable profile of side effects allowing prolonged treatment at low cumulative toxicity [4].

In conclusion, re-evaluation of HER2 status should be considered when patients with HER2 negative primary tumors (DAKO score 0 or $1+$ ) present with non-responding or progressive visceral metastases. As a simple option to estimate the current HER2 status of metastatic disease, determination of HER2 shed antigen may be considered.

\section{References}

1 McKeage K, Perry CM: Trastuzumab. Drugs 2002; 62:209-243.

2 Slamon DJ, Leyland-Jones, Shak S, Fuchs H, Paton V, Bajamonde A, Fleming T, Eiermann W, Wolter J, Pegram M, Baselga J, Norton L: Use of chemotherapy plus a monoclonal antibody against HER2. N Engl J Med 2001;344:783-792.

3 Burstein HJ, Harris LN, Marcom PK, LambertFalls R, Havlin K, Overmoyer B, Friedlander RJ, Gargiulo J, Strenger R, Vogel CL, Ryan PD, Ellis MJ, Nunes RA, Bunnell CA, Campos SM, Hallor M, Gelman R, Winer EP: Trastuzumab and vinorelbine as first-line therapy for HER2-overexpressing metastatic breast cancer: Multicenter phase II trial with clinical outcomes, analysis of serum tumor markers as predictive factors, and cardiac surveillance algorithm. J Clin Oncol 2003;21:28892895.

4 Jahanzeb M, Mortimer JE, Yunus F, Irvin DH, Speyer J, Koletsky AJ, Klein P, Sabir T, Kronish L: Phase II trial of weekly vinorelbine and trastuzum$\mathrm{ab}$ as first-line therapy in patients with HER2+ metastatic breast cancer. Oncologist 2002;7:410 417.
5 Simon R, Nocito A, Hubscher T, Bucher C, Torhorst J, Schraml P, Bubendorf L, Mihatsch MM, Moch H, Wilber K, Schotzau A, Kononen J, Sauter G. Patterns of HER2/neu amplification in primary and metastatic breast cancer. J Natl Cancer Inst 2001;93:1141-1146.

6 Gancberg D, DiLeo A, Cardoso F, Rouas G, Pedrocchi M, Paesmans M, Verhest A, BernardMarty C, Piccart MJ, Larsimont D: Comparison of HER-2 status between primary breast cancer and corresponding distant metastatic sites. Ann Oncol 2002;13:1036-1043.

7 Durbecq V, DiLeo A, Cardoso F, Rouas G, Leroy JY, Piccart M, Larsimont D: Comparison of topoisomerase Iialpha gene status between primary breast cancer and corresponding distant metastatic sites. Breast Cancer Res Treat 2003;77:199-204.

8 Cardoso F, DiLeo A, Larsimont D, Gancberg D, Rouas G, Dolci S, Ferreira F, Paesmans M, Piccart M: Evaluation of HER2, p53, bcl-2, topoisomerase II-alpha, heat shock proteins 27 and 70 in primary breast cancer and metastatic ipsilateral axillary lymph nodes. Ann Oncol 2001;12:615-620.
9 Remmele W, Stegner HE: Recommendation for uniform definition of an immunoreactive score (IRS) for immunohistochemical estrogen receptor detection (ER-ICA) in breast cancer tissue. Pathologe 1987;8:138-140.

10 Dowsett M, Cooke T, Ellis I, Gullick WJ, Gusterson B, Mallon E, Walker R: Assessment of HER2 status in breast cancer: Why, when and how? Eur J Cancer 2000;36:170-176.

11 Lüftner D, Dilk H, Henschke P, Geppert R, Dietel M, Stein H, Wernecke K, Possinger K, Heine B: Concordance of HER-2/neu expression of primary breast carcinomas and their metachronous distant metastases: Results of a 10 year retrospective search in two universitiy institutes of pathology. Eur J Cancer 2004;2 abstr \#163.

12 Domenech GH, Vogel CL: A review of vinorelbine in the treatment of breast cancer. Clin Breast Cancer 2001;2:113-128.

13 Vogel CL, Cobleigh MA, Tripathy D Gutheil JC, Harris LN, Fehrenbacher L, Slamon DJ, Murphy M, Novotny WF, Burchmore M, Shak S, Stewart SJ, Press M: Efficacy and safety of trastuzumab as a single agent in first-line treatment of HER2-overexpressing metastatic breast cancer. J Clin Oncol 2002;20:719-726. 